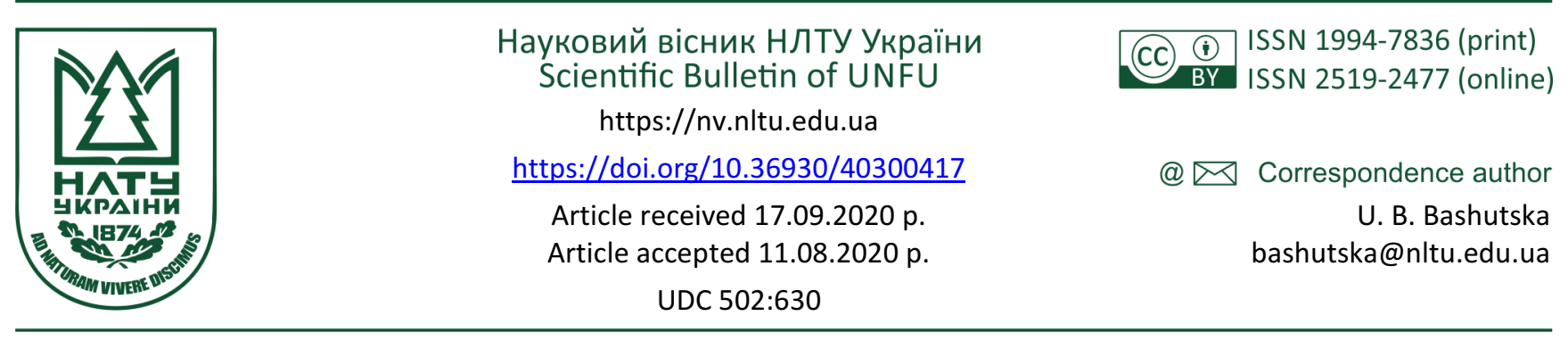

У. Б. Башуцька

Наиіональний лісотехнічний університет Украӥни, м. Львів, Украйна

\title{
ПОТЕНЦІАЛ ВИРОЩУВАННЯ РОБІНІЇ ЗВИЧАЙНОÏ (ROBINIA PSEUDOACACIA L.) НА ПОРУШЕНИХ ЗЕМЛЯХ СХІДНОЇ НІМЕЧЧИНИ
}

\begin{abstract}
Проаналізовано результати модельних проектів із розведення швидкозростаючих порід дерев для виробництва відновлюваної сировини в короткому циклі у лісових насадженнях та на рекультивованих після добування бурого вугілля землях Східної Німеччини. Особливу увагу звернено на робінію звичайну, оскільки ії рекомендують вирощувати на малопродуктивних і порушених землях, а не за рахунок площі корінних листяних насаджень. На дев'яти дослідних територіях Бранденбурга (Східна Німеччина) проводять випробування нових концепцій культивування робінії звичайної для енергетичного використання деревини. Розробляють шляхи мобілізації раніше невикористаних, але стабільно доступних запасів деревини робінії відповідно до "Національного плану дій щодо біомаси для Німеччини" (2009). Перевагу надають економічно обгрунтованому поводженню з наявними лісовими культурами робінії на малопродуктивних і рекультивованих землях. Встановлено придатність робінії звичайної для вирощування з метою енергетичного використання на малопродуктивних землях із невеликою кількістю опадів. Оцінено потенціал біомаси робінії звичайної у Бранденбурзі, який можна мобілізувати вирощуванням робінії в короткому плантаційному циклі. Інтенсивність росту робінії звичайної була високою вже в перший рік вирощування. Дослідження підтверджують важливість властивостей грунту, зокрема води, доступної рослинам, аерації грунту та глибини кореневмісного шару для продуктивного росту й розвитку саджанців робінії звичайної. Висока інтенсивність коренепаросткового відтворення робінії є сприятливою для ії вирощування з енергетичною метою. Застосування відповідної технології лісозаготівлі для невеликих площ та невеликий річний приріст за діаметром основи робінієвого пагона (на висоті зрізання приблизно 5 см) ускладнюють технологічний процес. Для його оптимізації потрібні короткі транспортні маршрути до споживача та можливості сушіння деревини. Висока щільність деревини робінії зумовлює високу теплоту згоряння іiї тріски. Робінія звичайна на малопродуктивних землях в умовах низької кількості опадів має високий приріст біомаси у перші п'ять років.
\end{abstract}

Ключові слова: енергетична деревина; робінія; порушені землі; лісова плантація; порослеве відновлення.

\section{Вступ}

Вплив лісу проявлясться не тільки на середовищі, в якому він зростає, а й поширюється на прилеглі нелісові території. Вважається, що ліс є відображенням зовнішніх природних умов і водночас впливає на зовнішне середовище і змінює його. При тривалому зростанні лісу в межах певної території середовищетвірне його значення на відміну від інших рослинних угруповань зводиться до істотних змін природних умов, що існували тут до появи насаджень. Вплив лісу на грунтові умови залежить від впливу його на мікроклімат і гідрологічні умови, тобто грунтотворення не може бути ізольованим від впливу цих чинників, а також підстеляючих грунтів материнських гірських порід.

Робінія звичайна (Robinia pseudoacacia L) - отруйна багаторічна рослина родини бобових, також відома під назвами робінія псевдоакація, колюча акація та біла акація, причому остання назва за популярністю перевершує наукову. Інші місцеві назви: акація фальшивка, вакація, горохівник, горохівник звичайний, горохівник кулястий, окація, робінія, ровинія. Дерево світлолюбне, жаро- та посухостійке, водночас доволі морозостійке і невибагливе до якості грунтів. У себе на батьківщині в східній частині Сполучених Штатів Америки - росте невеликими групами або поодиноко у листяних лісах. За межами природного ареалу цей вид найчастіше зростає у лісозахисних смугах та лісопарках, де можуть траплятися змішані й чисті насадження цієї культури. Навесні робінія звичайна розпочинає вегетацію найпізніше серед усіх дерев: іiі листя розпускається тільки на початку травня. Цвітіння відбувається у травні-червні.

Використання середовищетвірних і продукційних функцій робінії звичайної робить її перспективною у зв'язку із змінами клімату $[1,4,5,8,9,10,11,12,13,14$, 17]. Інвазивність цього виду дерев сприймається як загроза місцевим екосистемам $[5,8,9,12]$. Незважаючи на довгий час вирощування в Свропі, робінія звичайна досі залишається суперечливим деревним видом $[1,5,10$, $11,9,12,13,14,17]$. У Німеччині для привернення уваги охоронців природи, містобудівників та лісівників ії вибрано деревом року - "Дерево 2020 року: Робінія" (рисунок) [9].

\section{Інформація про автора:}

Башуцька Уляна Богданівна, канд. с.-г. наук, доцент, кафедра екологіï. Email: ecology@nltu.edu.ua; https://orcid.org/0000-0002-4131-014X

Цитування за ДСтУ: Башуцька У. Б. Потенціал вирощування робінії звичайної (Robinia pseudoacacia L.) на порушених землях Східної Німеччини. Науковий вісник НлтУ України. 2020, т. 30, № 4. С. 99-103.

Citation APA: Bashutska, U. B. (2020). Biomass potential of black locust (Robinia pseudoacacia L.) on the contaminated land of Eastern Germany. Scientific Bulletin of UNFU, 30(4), 99-103. https://doi.org/10.36930/40300417 
Спеціалісти висвітлюють інформацію щодо місця робінії в екологічно обгрунтованій концепції відновлення лісів, наголошують на можливості вагомого додаткового доходу для власника лісу за умови отримання високоякісних сортиментів деревини. Особливо актуальним це $\epsilon$ у час нинішньої складної ситуації на ринку деревини, що загрожує економічному стану багатьох лісогосподарських підприємств. Попит на високоякісну де-

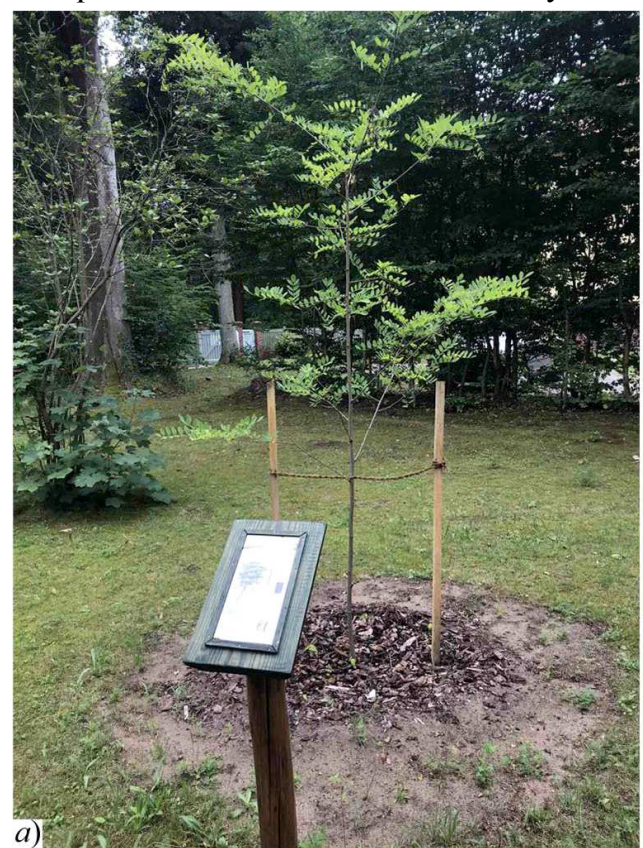

Рисунок. Робінія звичайна - дерево 2020 року (Фонд д-ра Сільвіуса б) таблиця із описом еколого-біологічних властивостей рослини

Об'єкт дослідження - модельні ділянки для вирощування робінії в короткому плантаційному циклі, зокрема на порушених добуванням бурого вугілля землях Східної Німеччини.

Предмет дослідження - динаміка загального приросту біомаси робінієвих насаджень залежно від лісорослинних умов модельної ділянки.

Мета дослідження: проаналізувати фактичну інформацію про особливості вирощування робінії звичайної в різних екотопах (діапазон від порівняно бідних піщаних техноземів до родючих бурих грунтів за трофністю та від сухих до помірно свіжих за зволоженням).

Для досягнення зазначеної мети потрібно виконати такі основні завдання дослідження: отримання даних про вихід біомаси і динаміку росту робінії звичайної у плантаційному господарстві енергетичної деревини на основі аналізу модельних ділянок у лісових насадженнях Бранденбурга та заліснених порушених землях Лаузіцького буровугільного басейну (Східної Німеччини).

Наукова новизна отриманих результатів дослідження: вперше на основі вивчення результатів східнонімецьких модельних проектів із розведення швидкозростаючих порід дерев для виробництва відновлюваної сировини в короткому циклі показано середньорічний загальний приріст біомаси робінієвих насаджень в різних умовах місцезростання. Особливу увагу приділено аналізу вирощування робінії звичайної на порушених добуванням бурого вугілля землях Східної Німеччини.

Практична значущість результатів дослідження: результати дослідження можуть бути використані у практиці планування виробництва відновлювальної сировини робінії звичайної на рекультивованих післягірничих ландшафтах України для забезпечення охорони ревину робінії залишається високим. Відзначають позитивний вплив робінії на грунти із низьким вмістом азоту, іiї незамінність під час рекультивації порушених земель і можливість вирощування плантацій енергетичної деревини [7, 9, 10, 11, 12, 13, 17]. Актуальність дослідження полягає у розширенні знань стосовно виходу біомаси та динаміки росту молодих рослин робінії на заліснених порушених землях.

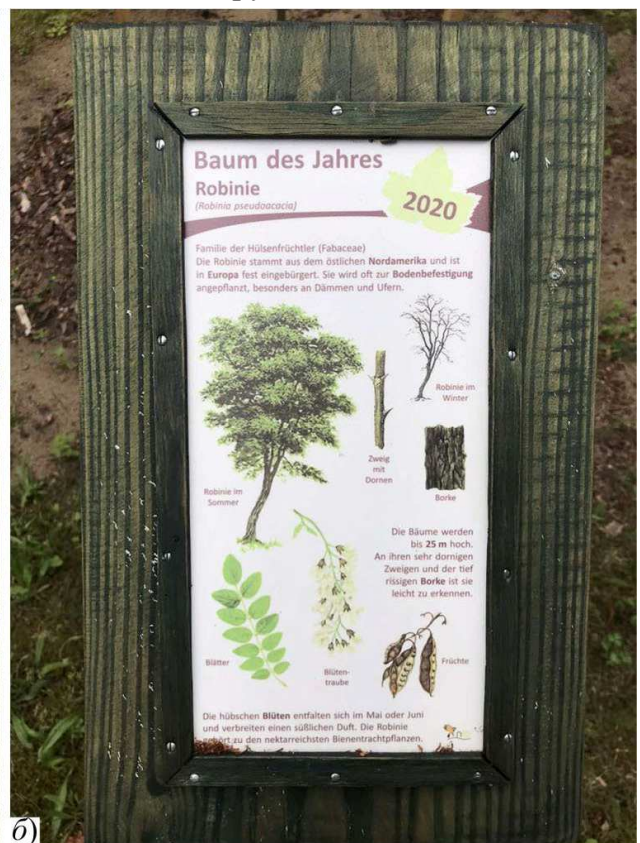

природи, а також раціонального користування природними ресурсами.

Аналіз останніх досліджень та публікацій. Швидкий ріст та висока енергетична цінність робінії звичайної роблять ії перспективною енергетичною деревиною для "зелених" технологій $[5,7,9,10,11,12,13,17]$. Теплота згоряння деревини робінії є значно вищою, ніж у бука, берези чи верби, і наближається до теплоти згоряння брикету бурого вугілля (табл. 1).

Табл. 1. Енергетична цінність видів палива [9]

\begin{tabular}{|l|c|}
\hline \multicolumn{1}{|c|}{ Паливо } & $\begin{array}{c}\text { Питома теплота } \\
\text { згоряння, кДж/кг }\end{array}$ \\
\hline Робінія (стовбур/серцевин $a$ ) & 18535 \\
\hline Робінія (порослеві пагони/заболонь) & 17493 \\
\hline Верба & 12170 \\
\hline Бук лісовий & 14400 \\
\hline Дуб скельний/дуб звичайний & 15199 \\
\hline Береза звичайна & 15500 \\
\hline Буре вугілля (брикет) & 19259 \\
\hline Мазут & 42707 \\
\hline
\end{tabular}

Продуктивне вирощування робінії можливе на піщаних грунтах з недостатнім зволоженням, де ріст тополі $€$ обмеженим через нестачу води. Робінію звичайну розглядають в умовах сухого літнього клімату та складних лісорослинних умов післягірничих ландшафтів альтернативною деревною породою [1, 2, 4, 5, 8, 9, 10, 11, 12, 13$]$.

Через низькі вимоги до місця зростання робінія заселяє екотопи із значними амплітудами екологічних чинників, уникаючи тільки заболочених і ущільнених грунтів. Це має особливо велике значення в умовах зміни клімату, зростання попиту на деревину та для лісомеліорації. Спектр використання біологічно стійкої де- 
ревини робінії для оздоблювально-будівельних робіт у приміщеннях і на відкритому повітрі є значно ширшим, ніж в інших деревних порід місцевих лісових насаджень $[5,7,9]$. Ïї деревина має унікальні властивості і є подібною до деревини ясена. Водночас вона $є$ твердішою, міцнішою і важчою, ніж у дуба. Низький ступінь набухання та всихання покращує ці властивості, тому деревина робінії $\epsilon$ оптимальною для виробництва інструментів, шахтних конструкцій, паль, будівельних брусів тощо [5, 9].

Робінію звичайну вважають в Україні інтродукованим деревним видом. Упродовж останнього століття іiі активно використовують у фітомеліорації через властивість фіксувати атмосферний азот внаслідок симбіотичної асоціації з діазотрофами $[1,2,4,5]$. Робінія звичайна у симбіозі із бульбочковими бактеріями забезпечує біологічну фіксацію азоту атмосфери, що $є$ дуже важливим для відтворення штучних екосистем. Це $є$ також екологічно чистий шлях постачання рослини зв'язаним азотом. Внаслідок цього робінія робить можливим поселення в бідних екотопах більш вимогливих до вмісту азоту в грунті видів дерев, але в природних клімаксних фітоценозах бобових фактично немає [1]. На бідних піщаних грунтах із низькою водоємкістю робінія має чіткі конкурентні переваги $[1,2,3,4,8,9,10$, $11,12,13]$.

Біологічні особливості дають змогу робінії мати вищу продуктивність у насадженнях, однак відсутність узгоджених заходів із догляду та довгострокового планування $є$ причинами нижчих запасів деревостанів. Високий вихід біомаси та динаміка росту є характерною для одно-п'ятирічних рослин робінії звичайної. Середньорічний загальний приріст пагонів є на четвертому році культивування близько 7,5 т сухої маси га $^{-1} \cdot$ рік $^{-1}$ [12]. Енергетичну деревину можна виробляти із базового діаметра пагона 4 cм. Набагато вигіднішим $є$ використання старших порослевих насаджень робінії. Наприклад, у 30-50-річних культурах робінії можна отримати чисті надходження близько 6000 євро· га ${ }^{-1}$ [12].

Ця посухостійка і термостійка вторинна лісотвірна порода набуває дедалі більшого значення через помітні зміни клімату [14]. Вона є високо конкурентною, показуючи швидкий ріст у молодому віці. Приріст біомаси в оптимальних умовах сягає 10 т сухої маси га ${ }^{-1} \cdot$ рiк $^{-1}$, а на легких рекультиваційних грунтах колишніх буровугільних розробок можливим $є$ отримання 7 т сухої маси га ${ }^{1} \cdot$ рiк $^{-1}$ [10]. Приблизно до 30-річного віку робінія звичайна перевершує за ростом усі інші лісові породи дерев [13].

Вирощування робінії звичайної в лісових насадженнях залишається до сьогодні спірним питанням [5, 9, 12]. Часто запас деревостану чи якість стовбурів не відповідають очікуванням $[5,7,9]$. Враховують також екологічні проблеми, необхідність збереження біорізноманіття $[1,5,9,10,11,12,13,14]$. Робінія звичайна може змінити стан екосистеми [1]. У бідних місцезростаннях вона може збагатити едафотоп поживними речовинами, покращуючи грунтові умови $[1,2,3,5,4,9,10,11,12$, $13,14]$. У малородючих, сухих і бідних поживними речовинами місцях вона може бути основою для подальших фаз розвитку лісу $[1,2,3,4,5,9]$. У разі механічного пошкодження робінії звичайної внаслідок зрізання під час лісозаготівлі відбувається збільшення росту через утворення пневої порослі і кореневого відростка [6,
$7,8,9,12,10,11,13,17]$. Здатність до вегетативного та генеративного розмноження робить усунення та витіснення робінії складним завданням. Екологічна інтеграція у природні або напівприродні лісові екосистеми обмежується через потенціал інвазивності. Однак в умовах зміни клімату робінію розглядають як альтернативний вид для збереження лісових насаджень у дуже сухих і бідних місцезростаннях $[1,4,5,8,9,10,11,12,13,14]$.

Матеріали та методи дослідження полягали в аналітичному опрацюванні тематичної літератури та наукових публікацій результатів модельних проектів із розведення швидкозростаючих порід дерев для виробництва відновлюваної сировини в короткому циклі (шість років). Експериментальні дослідження проводили вісім науково-дослідних установ різної форми власності та університети. Розглядали експериментальні умови масштабного та економного вирощування робінії звичайної для виробництва біомаси. Особливу увагу звернено на порушені добуванням бурого вугілля землі Східної Німеччини, які належать до модельних ділянок вирощування енергетичної деревини робінії.

Основою визначення авторами [12] біомаси були аллометричні функції. Для отримання регресійного співвідношення вимірювали і зважували 20 пагонів після заготівлі на плантаційній ділянці. Висота зрізання пагона становила 5 см. Обчислені функції майже збігалися. Результатом стало рівняння високої достовірності, яке використовувалося для визначення біомаси в молодих плантаційних культурах.

\section{Результати дослідження та їх обговорення}

Вивченню продукування надземної фітомаси робінією звичайною у плантаційних культурах, лісостанах та лісомеліораційних насадженнях на післягірничих територіях присвячені дослідні проекти $[12,17]$. Модельні ділянки розташовані в діапазоні від порівняно бідних піщаних техноземів до родючих бурих грунтів за трофністю та від сухих до помірно свіжих за зволоженням (табл. 2).

Для усіх ділянок характерний низький рівень залягання грунтових вод. У Мюнхеберзі та Швенуві 1 росту насаджень сприяє випаровування із водосховищ [11]. Для високих приростів робінії звичайній необхідні помірно багаті поживними речовинами субстрати. Водночас робінія звичайна $\epsilon$ незамінною деревною породою для рекультивації порушених земель через ії ефективне зв'язування атмосферного азоту.

Середньорічний загальний приріст біомаси робінієвих насаджень $є$ найвищим на четвертому році росту (табл. 3). До цього часу розвиток робінієвих насаджень був синхронізованим, але залежно від якості місця зростання існувала чітка градація ефективності.

Сприятливі лісорослинні умови ділянки Швенув 1 (родючі свіжі бурі грунти) забезпечили 10,7 т сухої маси $г^{-1} \cdot$ рiк $^{-1}$, а малосприятливі лісорослинні умови ділянки Швенув 3 (порівняно бідні помірно свіжі техноземи із бурих грунтів) - тільки 3,8 т сухої маси га ${ }^{-1} \cdot$ рік $^{-1}$. Помітною $є$ висока динаміка росту робінієвих насаджень: початкова тенденція росту відновилася після повторної заготівлі у п'ятому році. Водночас врожайність нівелювалася, за винятком двох повільноростучих насаджень Швенув 3 та Сенфтенберг. Біомаса пагонів робінії на молодих рекультивованих ділянках становить 29,4 т сухої маси га ${ }^{-1} \cdot$ piк $^{-1}$, що перевершує біомасу старих лісових насаджень робінії. 
Табл. 2. Опис модельних ділянок для вирощування робінії в короткому плантаційному циклі [12]

\begin{tabular}{|c|c|c|c|c|}
\hline Назва ділянки & Вік (2009) & Відносний висотний бонітет & Тип грунту & Умови місцезростання \\
\hline \multicolumn{5}{|c|}{ Лісові місцезростання в Бранденбурзі } \\
\hline Швенув 1 & 19 & $-0,1$ & бурі грунти & родючі свіжі \\
\hline Швенув 2 & 45 & II,3 & трепосол (технозем) із бурих грунтів & порівняно бідні помірно свіжі \\
\hline Швенув 3 & 45 & III,0 & трепосол (технозем) із бурих грунтів & порівняно бідні помірно свіжі \\
\hline Швенув 4 & 62 & 0,7 & бурі грунти & помірно родючі помірно свіжі \\
\hline Швенув 5 & 68 & 0,3 & псевдооглеєні бурі грунти & помірно родючі помірно свіжі \\
\hline Мюнхеберг & 56 & 0,1 & бурі грунти & помірно родючі помірно свіжі \\
\hline \multicolumn{5}{|c|}{ Заліснені порушені землі (Лаузіцьке буровугільне родовище) } \\
\hline Дребкау 1 & 20 & $\mathrm{I}, 6$ & $\begin{array}{c}\text { піщаний технозем із домішками ву- } \\
\text { гілля }\end{array}$ & бідні \\
\hline Дребкау 2 & 23 & II,7 & олігомінтний піщаний технозем & бідні \\
\hline Сенфтенберг & 43 & III,0 & полімінтний піщаний технозем & $\begin{array}{l}\text { порівняно бідні } \\
\text { помірно свіжі }\end{array}$ \\
\hline
\end{tabular}

Табл. 3. Середньорічний загальний приріст біомаси одно-п'ятирічних пагонів робінії у 2009-2013 рp. [12]

\begin{tabular}{|c|c|c|c|c|c|}
\hline \multirow[b]{2}{*}{ Назва ділянки } & \multicolumn{5}{|c|}{ Середньорічний загальний приріст біомаси, т сухої маси га ${ }^{-1} \cdot$ piк $^{-1}$} \\
\hline & $\begin{array}{l}\text { 1-річний оборот } \\
\text { (2009/2010/2011) }\end{array}$ & $\begin{array}{c}\text { 2-річний оборот } \\
(2009-2010)\end{array}$ & $\begin{array}{c}\text { 3-річна поросль } \\
\text { (2009-2011) }\end{array}$ & $\begin{array}{c}\text { 4-річна поросль } \\
\text { (2009-2012) } \\
\end{array}$ & $\begin{array}{c}\text { 5-річна поросль } \\
(2009-2013) \\
\end{array}$ \\
\hline \multicolumn{6}{|c|}{ Лісові місцезростання у Бранденбурзі } \\
\hline Швенув 1 & 7,61 & 10,54 & 7,36 & 10,68 & 8,79 \\
\hline Швенув 2 & 5,39 & 4,28 & 3,28 & 9,13 & 5,23 \\
\hline Швенув 3 & 2,22 & 1,52 & 1,15 & 3,83 & 1,94 \\
\hline Швенув 4 & 6,37 & 8,93 & 5,37 & 9,51 & 4,16 \\
\hline Швенув 5 & 5,56 & 6,10 & 5,63 & 8,83 & 4,20 \\
\hline Мюнхеберг & 3,51 & 2,86 & 5,84 & 6,77 & 4,74 \\
\hline \multicolumn{6}{|c|}{ Заліснені порушені землі (Лаузіцьке буровугільне родовище) } \\
\hline Дребкау 1 & 5,29 & 3,16 & 5,29 & 9,01 & 6,22 \\
\hline Дребкау 2 & 4,08 & 5,42 & 4,98 & 6,36 & 5,84 \\
\hline Сенфтенберг & 2,65 & 4,17 & 10,60 & 2,88 & - \\
\hline \multicolumn{6}{|c|}{ В середньому для: } \\
\hline лісових місцезростань & 5,11 & 5,71 & 4,77 & 8,13 & 4,84 \\
\hline $\begin{array}{c}\text { місцезростань } \\
\text { порушених земель }\end{array}$ & 4,01 & 4,25 & 6,95 & 6,08 & 6,03 \\
\hline всіх місцезростань & 4,74 & 5,22 & 5,50 & 7,45 & 5,14 \\
\hline
\end{tabular}

Чинники, що визначають врожайність робінієвої плантації, досі не встановлено. Окрім трофічних умов екотопу та його зволоження, $є$ й інші змінні, які раніше не були враховані за допомогою дисперсійного аналізу. Ними можуть бути погодні впливи, різна здатність генотипів робінії до регенерації і структура насадження (кількість і розподіл кореневищ). Популяції молодих рослин робінії $є$ вразливими до конкуренції трав'яних видів, грибкових захворювань та пошкодження гризунами.

До сьогодні заготівлю деревини у лісових насадженнях робінії, молодших десяти років, вважали недоцільною передусім через високі витрати [15]. Дослідженнями [6] навіть рекомендують заготівлю енергетичної деревини тільки із дерев робінії середнього діаметра на висоті грудей близько 17 см. Зараз випробовується технологія, яка є особливо ефективною у догляді за молодими насадженнями, зокрема на рекультивованих землях [12]. Вона є спеціально розробленою для догляду та заготівлі молодняку, забезпечує проміжне зберігання або попереднє сушіння. Функція "зв'язування" зменшує затрати праці, що дає змогу гнучко реагувати на вимоги ринку та коливання цін. Лісозаготівельна машина може зрізати ряд пагонів один за одним (місткість захоплення 40 см), зв'язувати їх та розміщувати вздовж трелювального волоку, одночасно обробляючи дерева завтовшки до 25 см 800-міліметровою циркулярною пилою [16]. Етапи технологічного процесу лісозаготівлі на модельних ділянках $є$ такі: a) зрізання дерева комбайном "PONSSE Beaver" (130 кВт) з агрегатом-підбирачем, б) підтягування трактором до трелювального волоку, в) необов'язкове попереднє висушування, г) подрібнення (мобільний подрібнювач), д) транспортування деревної стружки [12].

Розрахунок витрат (різниця виручки від реалізації деревини та змінних витрат) грунтується на ставках витрат за годину використання машини: комбайни середнього класу продуктивності з агрегатом-підбирачем 100 євро, трелювальний трактор - 100 євро, мобільний подрібнювач - 250 євро. Дохід від деревної тріски обчислюється в 100 євро за 1 т сухої маси із доставкою до заводу [7]. Детальний розрахунок здійснюють як чистий робочий час на виробництво однієї тонни сухої деревної тріски робінії. Порослеве відновлення робінії із високим запасом біомаси, яке потребує від 80 до 160 хв загального робочого часу на виробництво 1 т сухої тріски, не забезпечує позитивного покриття витрат. Під час збирання врожаю потрібно в середньому чотири грейферні захвати для одного порослевого пня. Масовий захват порослі виконати складно. Продуктивність праці підвищується залежно від середньої маси порослевого пагона. Часткове покриття витрат досягається при загальному робочому часі 57 хв на виробництво $1 \mathrm{~T}$ сухої тріски. Це відповідає середньому діаметра порослевого пагона 40 мм (приблизно шостий-восьмий рік) [12]. Технологічні етапи лісозаготівлі "зрізання-зв'язування" п'ятирічних пагонів тополі та верби (діаметр пагона на висоті зрізання 5 см є меншим ніж 50 мм) не $\epsilon$ економічно вигідними [15]. Збільшення середньої маси заготівельного пагона енергетичної лісової культури забезпечує кращий економічний ефект [12]. 


\section{Висновки}

Робінія звичайна є мало дослідженим видом у плантаційному господарстві енергетичної деревини, який відзначається високим виходом біомаси та динамічним зростанням. Її середньорічний загальний приріст досяг максимуму на четвертому році росту - 7,5 т сухої маси $\mathrm{ra}^{-1} \cdot$ рік $^{-1}$. Градацію продуктивності можна визначити залежно від умов місцезростання, але загалом робінія в перші роки росту перевершує всі інші породи лісових дерев. Застосування нових технологій заготівлі енергетичної деревини у 6-8-річних насадженнях робінії дає змогу покривати частину витрат. Рентабельною є заготівля деревини у 30-50-річних насадженнях робінії. Для вирощування робінії звичайної відводять малопродуктивні грунти післягірничих ландшафтів, оскільки швидкозростаюча робінія у сприятливих умовах місцезростання створює істотну конкуренцію місцевим деревним породам. На порушених землях цей вид $є$ непроблемним $з$ екологічного погляду. Він дає змогу виконати одне із основних завдань лісомеліорації- відновлення природної екосистеми після техногенного втручання, враховуючи екологічні аспекти та принцип стійкості, а також має високий потенціал біомаси. Збереження корисних функцій робінієвих насаджень на порушених землях за раціонального користування біомасою має важливе значення для задоволення суспільних потреб.

\section{References}

1. Работнов, Т. А. Фитоценология. Москва: Изд-во МГУ, 1983, $292 \mathrm{p}$.

2. Умаров, М. М. Ассочиативная азотфиксаиия. Москва: Издво МГУ, 1986, $132 \mathrm{p}$.

3. Bashutska, U. (2020). Importance of landscape after brown coal mining in Eastern and Central Germany for the nature protection. Scientific Bulletin of UNFU, 30(2), 55-61. https://doi.org/10.36930/40300210

4. Bashutska, U. B. (2006). Suktsesii roslynnosti porodnykh vidvaliv shakht Chervonohradskoho hirnychopromyslovoho raionu. Monograph. Lviv: RVV NLTU Ukrainy, $181 \mathrm{p}$.

5. Bashutska, U., \& Cremer, T. (2020). Ecological assessment of black locust wood and coal-mining dumps, as a reserve area for its cultivation Scientific Bulletin of UNFU, 30(3), 51-59. https://doi.org/10.36930/40300309
6. Becker, G. (2006). Die Wald-Holz-Kette für HolzhackschnitzelBereitstellungsformen von Energieholz aus dem Wald. Vortrag am 22.05.2006 im Forum Daun, 27 p.

7. C.A.R.M.E.N. e.V. (2012). Centrales-Agrar-Rohstoff-Marketingund Energie-Netzwerk E. V. Energiewende-Presseschau: Neue Ausgabe erschienen. Retrieved from: http://www.carmenev.de/dt/energie/hackschnitzel/hackschnitzelpreis_grafiken.html

8. Kleinbauer, I., Dullinger, S., Peterseil, J., \& Essl, F. 2010: Climate change might drive the invasive tree Robinia pseudoacacia into nature reserves and endangered habitats. Biological Conservation, $143,382-390$.

9. Knoche, D. (2016). Holzeigenschaften und Bewirtschaftung der Robinie, Baum des Jahres - Dr. Silvius Wodarz Stiftung - 21385 Rehlingen. Retrieved from: www.baum-des-jahres.de

10. Knoche, D., \& Engel, J. (2012). Robinie: Lichtbaumart beendet ihr Schattendasein - Brandenburg erprobt Schnellwuchsbetrieb als nachfrageorientierte Bewirtschaftungsstrategie für die Robinie. Holz-Zentralblatt, 1, 16-17.

11. Knoche, D., \& Engel, J. (2012). Verbundvorhaben. Züchtung schnellwachsender Baumarten für die Produktion nachwachsender Rohstoffe im Kurzumtrieb. Beiträge aus der Nordwestdeutschen Forstlichen Versuchsanstalt. Band 8, 143-164.

12. Knoche, D., Lange, C., \& Engel, J. (2015). Entwicklung von innovativen Bewirtschaftungsverfahren für Robinienbestände (Robinia pseudoacacia L.). FastWOOD II: Züchtung schnellwachsender Baumarten für die Produktion nachwachsender Rohstoffe im Kurzumtrieb, Thünen Report, 26, 71-85.

13. Lockow, K.-W., \& Lockow, J. (2013). Die Robinie (Robinia pseudoacacia L.). Eine schnellwachsende Baumart mit wertvollen Holzeigenschaften. Mitt. d. Ges. zur Förderung schnellwachsender Baumarten in Norddeutschland e. V., Heft, 1, 1-7.

14. Roloff, A., \& Grundmann, B, (2008). Klimawandel und Baumarten-Verwendung für Waldökosysteme. Forschungsstudie, 6-37. Retrieved from: http://www.waldundklima.de/klima/klima_docs/swin_roloff_klam_2008.pdf

15. Rupprecht, S, (2012). Die Rentabilität der Robinie (Robinia pseudoacacia L.) im Land Brandenburg bei Nieder-, Mittel- und Hochwaldbewirtschaftung. Masterarbeit, Fachrichtung Umweltwissenschaften, Masterstudiengang Raumentwicklung und Naturressourcenmanagement, Technische Universität Dresden (TUD).

16. Stoll, B., \& Burger, F. (2012). Fäller-Bündler-Technologie in der KUP-Ernte. LWF-aktuell, 90, 18-19.

17. Zweihiebige Erstaufforstungen - Integration von Kurzumtriebsbestockungen in Erstaufforstungen. Heft D3. Retrieved from: https://www.wald-mv.de/static/Wald-mv/Dateien/Gruener Ordner/Heft D-3 LandesforstMV_einseitig.pdf

U. B. Bashutska

Ukrainian National Forestry University, Lviv, Ukraine

\title{
BIOMASS POTENTIAL OF BLACK LOCUST (ROBINIA PSEUDOACACIA L.) ON THE CONTAMINATED LAND OF EASTERN GERMANY
}

\begin{abstract}
The results of model projects on breeding fast-growing tree species for the production of renewable raw materials in a short cycle in forest plantations and on lands contaminated after the mining of brown coal in Eastern Germany are analyzed. Particular attention was paid to black locust. It is recommended to be grown on unproductive and contaminated lands, and not at the expense of the area of the native deciduous trees. New concepts for cultivating black locust for energy and material use of wood were tested in nine trial plots in Brandenburg (Eastern Germany). The ways to mobilize previously unused but available stable stocks of robinia wood are being developed in accordance with the National Biomass Action Plan for Germany (2009). Preference was given to the economically justified treatment of existing hard-to-reach forest crops of black locust on unproductive and contaminated lands. The suitability of black locust for cultivation for energy use in unproductive places with low rainfall has been established. The biomass potential of black locust in Brandenburg, which can be mobilized by growing black locust in a short plantation cycle, has been assessed. The growth rate of black locust was found to be high in the first year of cultivation. The studies conducted confirm the importance of soil properties, in particular water available to plants, soil aeration and the depth of the root layer for productive growth and development of black locust seedlings. The high intensity of black locust root reproduction is favourable for growing its forest crops for energy purposes. The application of appropriate logging technology for small areas and a small annual increase by the diameter of the base of the black locust shoot (at a cutting height of about $5 \mathrm{~cm}$ ) complicates the technological process. Its optimization requires short transport routes to the consumer and the ability to dry wood. High density of black locust wood causes the high heat of the combustion of its chips. Black locust on low-yielding lands with low rainfall has a high biomass increase in the first five years of growth.
\end{abstract}

Keywords: energy wood; black locust; contaminated land; a forest plantation; root reproduction. 